\title{
Effects of polycyclic aromatic hydrocarbons on the proliferation and differentiation of placental cells
}

\author{
Yun Sung Jo ${ }^{\dagger}$, Hyun Sun Ko ${ }^{\dagger}$, Ah Young Kim, Ha Gyeong Jo, Woo Jung Kim and Sae Kyung Choi* (i)
}

\begin{abstract}
Background: The purpose of this study was to investigate the effects of polycyclic aromatic hydrocarbons (PAHs) other than bisphenol A (BPA) and BPA substitutes on placental cells.

Methods: HTR-8/SVneo cells were treated with anthracene, benzo[k]fluoranthene, benzo[a]pyrene, and 4,4-(9-fluorenylidene)diphenol, which is used as a substitute for BPA-free products. After confirming the dose response for each reagent using the prepared cells, the cells were incubated for 24,48 , and $72 \mathrm{~h}$. Cell viability was confirmed using the XTT assay. Each experiment was performed with the minimum number of samples $(n=3)$ required for statistical analysis. The results were analyzed using t-tests; $p<0.05$ was considered statistically significant.
\end{abstract}

Results: After treatment with anthracene, benzo[k]fluoranthene, benzo[a]pyrene, and 4,4-(9-fluorenylidene)diphenol, the absorbance measured using the XTT assay decreased significantly with increasing concentration. The absorbance decreased significantly over time following treatment with each endocrine disruptor at the concentration confirmed by the dose-response analysis.

Conclusions: This study showed that anthracene, benzo[k]fluoranthene, benzo[a]pyrene, and 4,4-(9-fluorenylidene) diphenol—a BPA substitute—affect cell viability and necrosis in the placental cell line. The study indicates the serious effects of PAHs that negatively affect pregnancy but were previously unknown. Further, this study would serve as a reference for the identification of harmful PAHs during pregnancy prognosis in women who are more susceptible to PAH exposure.

Keywords: Pregnancy, Placenta, Endocrine disruptors, Anthracene, Female reproduction, Polycyclic aromatic hydrocarbons

\section{Background}

Endocrine disruptors are chemicals that can disrupt the endocrine system in both humans and animals. Female reproductive ability is an important process regulated by hormones and is susceptible to exposure to endocrine-disrupting substances. Endocrine disruptors have

\footnotetext{
*Correspondence: obgysk@catholic.ac.kr

†Yun Sung Jo and Hyun Sun Ko contributed equally to this work.

Department of Obstetrics and Gynecology, College of Medicine, The Catholic University of Korea, 222, Banpo-daero, Seocho-gu, Seoul 06591, Republic of Korea
}

a benzene ring structure similar to that of steroid hormones among several female hormones. Therefore, they can easily affect reproductive hormones with a benzene ring structure $[1,2]$. Female reproductive disorders caused by endocrine disruptors can lead to inadequate hormone production, infertility, anovulation, premature ovarian failure, and menstrual disorders. Various endocrine disruptors have been reported to disrupt the endocrine system in reproductive-aged women and to cause congenital disabilities [3, 4].

Polycyclic aromatic hydrocarbons (PAHs), which are endocrine disruptors, are common environmental original author(s) and the source, provide a link to the Creative Commons licence, and indicate if changes were made. The images or other third party material in this article are included in the article's Creative Commons licence, unless indicated otherwise in a credit line to the material. If material is not included in the article's Creative Commons licence and your intended use is not permitted by statutory regulation or exceeds the permitted use, you will need to obtain permission directly from the copyright holder. To view a copy of this licence, visit http://creativecommons.org/licenses/by/4.0/. The Creative Commons Public Domain Dedication waiver (http://creativeco mmons.org/publicdomain/zero/1.0/) applies to the data made available in this article, unless otherwise stated in a credit line to the data. 
pollutants released by incomplete combustion processes. PAHs emitted into our living environment are of interest because they have harmful side effects to humans, such as teratogenicity, mutagenicity, and carcinogenicity [5]. PAHs enter the body primarily through inhalation and ingestion. In pregnant women, PAHs that enter the body induce side effects on the mother, which are also transmitted through the placenta to the fetus, causing severe fetal developmental problems [6]. The growth and function of the placenta are regulated and coordinated to perform the placental role efficiently during pregnancy. If PAHs are transmitted from the mother to the fetus through the placenta, they negatively affect fetal growth. In addition, exposure to harmful substances such as PAHs during pregnancy can lead to disability even after the fetus grows into an adult [7].

A recent study analyzed the correlation between preterm labor and the concentration of PAHs in the placenta of women living in areas with high PAH exposure. This study showed that high PAH concentration, DNA products exposed to PAHs, and regulation of endocrine metabolic pathways affect preterm labor in pregnant women living near areas contaminated with environmental pollutants.

Given the results of these studies, exposure to PAHs during pregnancy is a critical issue in terms of teratogenicity, fetal growth, and preterm labor. However, there are various PAH types, and the studies so far have mainly focused on bisphenol A (BPA) and some phthalates. Therefore, we experimented on the PAHs that have not been studied for their effects on pregnancy. We examined cell viability and necrosis in a placental cell line treated with the selected PAHs. This study indicates the serious effects of PAHs that negatively affect pregnancy but were previously unknown. Moreover, the study is a reference for the identification of harmful PAHs during pregnancy prognosis in women who are more susceptible to $\mathrm{PAH}$ exposure.

\section{Methods}

\section{Chemicals and reagents}

Four PAHs, which have not been explored for their effects on pregnancy, were selected for experimentation on cell viability and necrosis in a placental cell line treated with the selected PAHs. In addition, 4,4-9(fluorenylidene)diphenol, a BPA substitute, which was recently used in BPA-free products, was also studied for its effect on cell viability and necrosis in a placental cell line.

PAHs used in this experiment are as follows:

1. Anthracene (Sigma-Aldrich, St Louis, MO USA, $\# 07,671-100 \mathrm{mg}$ )
2. Benzo[k]fluoranthene (Sigma-Aldrich, St Louis, MO USA, \#03,323-10 mg)

3. Benzo[a]pyrene (Sigma-Aldrich, St Louis, MO USA, \#51,968-50 mg)

4. 4,4-(9-Fluorenylidene)diphenol (BPA substitute) (Sigma-Aldrich, St Louis, MO USA, \#399,981-25 g)

\section{Cell culture and treatment}

The human placental HTR-8/SVneo cell line was provided by Queen's University (Ontrio, Canada). HTR-8/ SVneo cells were seeded in $100-\mathrm{mm}$ culture plates at a density of $1 \times 10^{6}$, followed by starvation for $24 \mathrm{~h}$ to increase the effectiveness of the substance to be treated. After the cells were grown up to $80 \%$ confluency in the plate containing RPMI 1640 medium without fetal bovine serum (Gibco, CAT NO. \#21,875,034), the serumfree medium was removed, the cells were washed lightly with phosphate-buffered saline to remove all traces of the medium, and were then treated with trypsin/EDTA. After treatment with trypsin/EDTA for $1 \mathrm{~min}$, the plate was tapped lightly on one side for the detachment of the cells from the bottom of the plate. After removing the cells, $10 \mathrm{~mL}$ of serum-free medium was evenly sprayed into the plate to remove all remaining cells from the bottom, and the solution containing the cells was collected, and transferred to a 15-mL Eppendorf tube. The solution containing the cells was centrifuged at $200 \times \mathrm{g}$ for 10 min (Centrifuge 5810r, Eppendorf). After centrifugation, we the supernatant was discarded and $4 \mathrm{~mL}$ of RPMI 1640 medium was added to the pellet. Then, $1 \mathrm{~mL}$ of cell suspension was transferred into a microtube, and the cells were detached once again, following which, 20 $\mu \mathrm{L}$ of the cell suspension was transferred into another microtube. After the sufficient mixing of the cell suspension, $20 \mu \mathrm{L}$ of the cell suspension was injected into the narrow groove of the prepared hemocytometer using a pipette. We counted the cells in 4 squares of the hemocytometer mounted on a microscope at $\times 10$ magnification. The diluted cells of $100 \mu \mathrm{L}$ each were transferred in three compartments of 96-well microtiter plates in triplicate. Only the cell-free medium $(100 \mu \mathrm{L})$ was separately added into the three compartments and was used as a blank. The seeded plates were incubated for $12 \mathrm{~h}$ at $37^{\circ} \mathrm{C}$ in $5 \%$ $\mathrm{CO}_{2}$. After confirming that the cells were attached to the plate using a microscope, the cells were treated with each PAH separately and cultured.

\section{Dose response}

Prior to the experiment, we attempted to determine the effective concentration of each PAH to use in timeresponse experiments with PAHs. The prepared cells were incubated for $24 \mathrm{~h}$ at predetermined concentrations 
(Table 1) [8-10]. After dissolving PAHs in dimethyl sulfoxide, they were diluted with RPMI 1640 medium at different concentrations. The cells were cultured with $0 \mu \mathrm{g} /$ $\mathrm{mL}, 0.05 \mu \mathrm{g} / \mathrm{mL}, 0.5 \mu \mathrm{g} / \mathrm{mL}, 5 \mu \mathrm{g} / \mathrm{mL}$, and $50 \mu \mathrm{g} / \mathrm{mL}$ of anthrane; $0 \mu \mathrm{g} / \mathrm{mL}, 0.3 \mu \mathrm{g} / \mathrm{mL}, 3 \mu \mathrm{g} / \mathrm{mL}, 30 \mu \mathrm{g} / \mathrm{mL}$, and $300 \mu \mathrm{g} / \mathrm{mL}$ of benzo[k]fluoranthene; $0 \mu \mathrm{g} / \mathrm{mL}, 0.1 \mu \mathrm{g} /$ $\mathrm{mL}, 1 \mu \mathrm{g} / \mathrm{mL}, 10 \mu \mathrm{g} / \mathrm{mL}$, and $100 \mu \mathrm{g} / \mathrm{mL}$ of benzo[a]pyrene; $0 \mu \mathrm{g} / \mathrm{mL}, 0.005 \mu \mathrm{g} / \mathrm{mL}, 0.05 \mu \mathrm{g} / \mathrm{mL}, 0.5 \mu \mathrm{g} / \mathrm{mL}$, and $5 \mu \mathrm{g} / \mathrm{mL}$ of 4,4-(9-Fluorenylidene)diphenol. Cell growth and viability were examined by measuring absorbance using the XTT assay (XTT Cell Proliferation Assay Kit, American Type Culture Collection, Manassas, VA, USA) at $450-650 \mathrm{~nm}$. The concentration of PAH showing a statistically significant change in optical density (OD) was compared with the respective control.

\section{Time response}

The most effective concentration confirmed for each $\mathrm{PAH}$ in the dose-response experiment was used to incubate the prepared cells for 24,48 , and $72 \mathrm{~h}\left(5 \% \mathrm{CO}_{2}\right.$, humidified atmosphere at $37{ }^{\circ} \mathrm{C}$ ). The OD value for each incubation time was determined using the XTT assay.

\section{XTT assay}

An XTT solution was prepared by dissolving $1 \mathrm{~mL}$ of activation reagent (sterile solution containing $\mathrm{N}$-methyl dibenzopyrazine methyl sulfate) with $5 \mathrm{~mL}$ of XTT reagent at $37^{\circ} \mathrm{C}$ immediately before use. Then, $50 \mu \mathrm{L}$ of the solution was added to each well, incubated at $37^{\circ} \mathrm{C}$ in a $\mathrm{CO}_{2}$ incubator for $3 \mathrm{~h}$, and the plate was slowly shaken manually until the solution turned orange. The absorbance of the wells containing cells and blank background control was measured at $450-500 \mathrm{~nm}$ using a microtiter plate reader. The absorbance of the cell-containing wells and control wells was also measured at $630-690 \mathrm{~nm}$ to assess non-specific readings. We determined the average value from the triplicate readings and subtracted the average value for the blank wells as well as the average value of the non-specific readings. When performing the $\mathrm{XTT}$ assay, the following parameters were used:

Specific absorbance filter: $475 \mathrm{~nm}$

Non-Specific absorbance filter: $660 \mathrm{~nm}$

The specific absorbance of the sample was calculated using the following formula:

Specific $\quad$ absorbance $=\mathrm{A}_{475 \mathrm{~nm}} \quad($ Test $)-\mathrm{A}_{475 \mathrm{~nm}}$ (Blank) - $\mathrm{A}_{660 \mathrm{~nm}}$ (Test).

\section{Statistical analysis}

Each experimental group was conducted with the minimum number $(n=3)$ required for statistical analysis.

Table 1 Absorbance of HTR8/SVneo according to the exposure dose of the endocrine disruptors

\begin{tabular}{|c|c|c|c|c|c|c|}
\hline \multirow{2}{*}{$\begin{array}{l}\text { Materials } \\
\text { Anthracene }\end{array}$} & \multirow{2}{*}{$\begin{array}{l}\text { Doses }(\mu \mathrm{g} / \mathrm{mL}) \\
0\end{array}$} & \multicolumn{4}{|c|}{ O.D. (Individuals) } & \multirow{2}{*}{$\begin{array}{l}\text { O.D. (Total, } n=4) \\
1.530 \pm 0.029\end{array}$} \\
\hline & & 1.502 & 1.534 & 1.572 & 1.510 & \\
\hline & 0.05 & 1.500 & 1.520 & 1.566 & 1.475 & $1.515 \pm 0.036$ \\
\hline & 0.5 & 1.469 & 1.501 & 1.508 & 1.400 & $1.470 \pm 0.046^{*}$ \\
\hline & 5 & 1.414 & 1.469 & 1.453 & 1.345 & $1.420 \pm 0.051^{* *}$ \\
\hline & 50 & 1.385 & 1.419 & 1.399 & 1.260 & $1.366 \pm 0.067^{* *}$ \\
\hline \multirow[t]{5}{*}{ Benzo[k]fluoranthene (B[k]F) } & 0 & 1.543 & 1.555 & 1.570 & 1.552 & $1.555 \pm 0.010$ \\
\hline & 0.3 & 1.569 & 1.574 & 1.564 & 1.560 & $1.567 \pm 0.006$ \\
\hline & 3 & 1.546 & 1.539 & 1.567 & 1.542 & $1.549 \pm 0.012$ \\
\hline & 30 & 1.540 & 1.524 & 1.549 & 1.539 & $1.538 \pm 0.010^{*}$ \\
\hline & 300 & 1.510 & 1.508 & 1.483 & 1.500 & $1.500 \pm 0.011^{* *}$ \\
\hline \multirow[t]{5}{*}{ Benzo[a]pyrene (B[a]P) } & 0 & 1.560 & 1.575 & 1.522 & 1.547 & $1.551 \pm 0.021$ \\
\hline & 0.1 & 1.505 & 1.592 & 1.500 & 1.541 & $1.535 \pm 0.039$ \\
\hline & 1 & 1.582 & 1.547 & 1.510 & 1.538 & $1.544 \pm 0.027$ \\
\hline & 10 & 1.481 & 1.502 & 1.494 & 1.504 & $1.495 \pm 0.010^{* *}$ \\
\hline & 100 & 1.205 & 1.464 & 1.470 & 1.429 & $1.392 \pm 0.117^{*}$ \\
\hline \multirow[t]{5}{*}{ Fluorene-9-bisphenol (BHPF) } & 0 & 1.541 & 1.509 & 1.512 & 1.572 & $1.534 \pm 0.027$ \\
\hline & 0.005 & 1.550 & 1.481 & 1.515 & 1.571 & $1.529 \pm 0.037$ \\
\hline & 0.05 & 1.521 & 1.479 & 1.473 & 1.599 & $1.518 \pm 0.054$ \\
\hline & 0.5 & 1.500 & 1.452 & 1.465 & 1.555 & $1.493 \pm 0.043$ \\
\hline & 5 & 1.401 & 1.429 & 1.391 & 1.462 & $1.421 \pm 0.029^{* *}$ \\
\hline
\end{tabular}

Total values are mean \pm SEM

Significantly different from control; $p<0.05^{*}, p<0.005^{*}$ 
The results were analyzed using Mann-Whitney test and Kruskal-Wallis test; $p<0.05$ was considered statistically significant.

\section{Results}

\section{Dose response}

OD was measured at $450-650 \mathrm{~nm}$. The absorbance before exposure to anthracene was $1.530 \pm 0.029$, but as the concentration increased, the OD value decreased. For anthracene at $0.5 \mu \mathrm{g} / \mathrm{mL}$ concentration, the OD was $1.470 \pm 0.046$, which was significantly lower than that before treatment $(p<0.05)$. When the cells were treated with 5 and $50 \mu \mathrm{g} / \mathrm{mL}$ anthracene, the OD values were also significantly lower than before the treatment $(1.530 \pm 0.029$ vs. $1.420 \pm 0.051, p<0.005 ; 1.530 \pm 0.029$ vs. $1.366 \pm 0.067, p<0.005$, respectively).

In HTR-8/SVneo cells treated with increasing benzo[k] fluoranthene concentrations $(3 \mu \mathrm{g} / \mathrm{mL})$, the absorbance decreased with an increase in concentration. When the concentration reached $30 \mu \mathrm{g} / \mathrm{mL}$, there was a significant difference as compared to the effect before treatment ( $1.555 \pm 0.010$ vs. $1.538 \pm 0.010, p<0.05$, respectively). After treatment with $300 \mu \mathrm{g} / \mathrm{mL}$ benzo[k]fluoranthene, the absorbance was $1.500 \pm 0.011$, which was significantly lower than that of the control $(p<0.005)$.

With benzo[a]pyrene concentration of $10 \mu \mathrm{g} / \mathrm{mL}$ and $100 \mu \mathrm{g} / \mathrm{mL}$, the absorbance was significantly lower than that of the control $(1.551 \pm 0.021$ vs. $1.495 \pm 0.010$, $p<0.005 ; 1.551 \pm 0.021$ vs. $1.392 \pm 0.117, p<0.05$, respectively). Treatment with 4,4-(9-fluorenylidene)diphenol, which is a substitute for BPA, showed a significant difference in absorbance when treated with $5 \mu \mathrm{g} / \mathrm{mL}$ $(1.534 \pm 0.027$ vs. $1.421 \pm 0.029, p<0.005)$ (Table 1 and Fig. 1).

\section{Time response}

The change in absorbance over time was confirmed by treatment with the endocrine disruptor at the dose verified in the dose-response experiment (Table 2 and Fig. 2). The initial absorbance obtained following the treatment of HTR-8/SVneo cells with anthracene $(50 \mu \mathrm{g} / \mathrm{mL})$ was $1.517 \pm 0.011$, which showed a tendency to decrease to $1.402 \pm 0.068(p<0.05)$ at $24 \mathrm{~h}, 1.097 \pm 0.132(p<0.05)$ at $48 \mathrm{~h}$, and $0.568 \pm 0.141(p<0.005)$ at $72 \mathrm{~h}$. The absorbance following treatment with $300 \mu \mathrm{g} / \mathrm{mL}$ of benzo[k]fluoranthene was also significantly lower than the initial value at 24,48 , and $72 \mathrm{~h}(1.545 \pm 0.025$ vs. $1.513 \pm 0.010, \mathrm{p}<0.05$; $1.545 \pm 0.025$ vs. $1.495 \pm 0.017, p<0.05 ; 1.545 \pm 0.025$ vs. $1.483 \pm 0.015, \mathrm{p}<0.005)$. The absorbance for the treatment with benzo[a]pyrene at a concentration of $100 \mu \mathrm{g} /$ $\mathrm{mL}$, as confirmed by the XTT assay, showed a significant difference after $24 \mathrm{~h}(1.553 \pm 0.023$ vs. $1.426 \pm 0.056$, $p<0.005 ; \quad 1.553 \pm 0.023$ vs. $1.139 \pm 0.072, \quad p<0.005$;
$1.553 \pm 0.023$ vs. $0.730 \pm 0.020, p<0.005)$. Similar results were also observed when the cells were treated with $5 \mu \mathrm{g} /$ $\mathrm{mL}$ of 4,4-(9-fluorenylidene)diphenol. When compared with the initial OD value, the absorbance was statistically significantly lower than that of the control at $24 \mathrm{~h}$, $48 \mathrm{~h}$, and $72 \mathrm{~h}(1.539 \pm 0.025$ vs. $1.419 \pm 0.022, p<0.005$; $1.539 \pm 0.025$ vs. $1.376 \pm 0.039, p<0.005 ; 1.539 \pm 0.025$ vs. $1.236 \pm 0.089, p<0.005)$.

\section{Discussion}

In this study, we evaluated changes in the placental cell line treated with PAHs to determine the effects of PAHs on cell viability and necrosis. We found that the absorbance measured using the XTT assay decreased with an increase in the concentrations of PAHs and time in HTR-8/SVneo cells treated with anthracene, benzo[k] fluoranthene, benzo[a]pyrene, and 4,4'-(9-fluorenylidene) diphenol. This result indicates a positive correlation between the above PAHs and cell necrosis according to the dose and time in the placental cell line.

The placenta plays an important role in nutrient transport and fetal growth during pregnancy. The formation of a spiral artery from the placenta provides an uninterrupted supply of nutrient-rich maternal blood to the fetus by the end of the first trimester [11]. Human placental growth hormone, human chorionic gonadotropin, progesterone, estradiol, and placenta lactogen are secreted from the human placenta; all play a crucial role in pregnancy and fetal development [12]. Several studies have reported that exposure to PAHs in pregnant women may be associated with many changes in fetal and pregnancy outcomes, including pregnancy loss, changes in the onset of labor, such as preterm delivery, and abnormal fetal growth. In addition, it has been reported that the placenta may play a mediating role in these endocrine disruptors during pregnancy [13-17]. Our results showed that the placenta exposed to PAHs may be adversely affected, leading to complications during pregnancy.

In particular, the loss of cell viability in the placenta is associated with premature labor. We provide experimental evidence to prove that PAHs induce preterm labor by confirming that PAHs evoke necrosis of placental cells. In a study investigating the correlation between the PAH concentration in the placenta and preterm labor in women exposed to high PAH exposure, it was found that the concentration and DNA products of PAHs affect preterm labor. They reported that the concentrations of benzo[a]pyrene, benzo[b]fluorene, and dibenzo[a,h] anthracene were higher in the placenta of pregnant women with preterm delivery than in those with fullterm delivery [18].

There are some limitations to our study. The HTR-8/ SVneo cell line used in our study is considered a mixed 


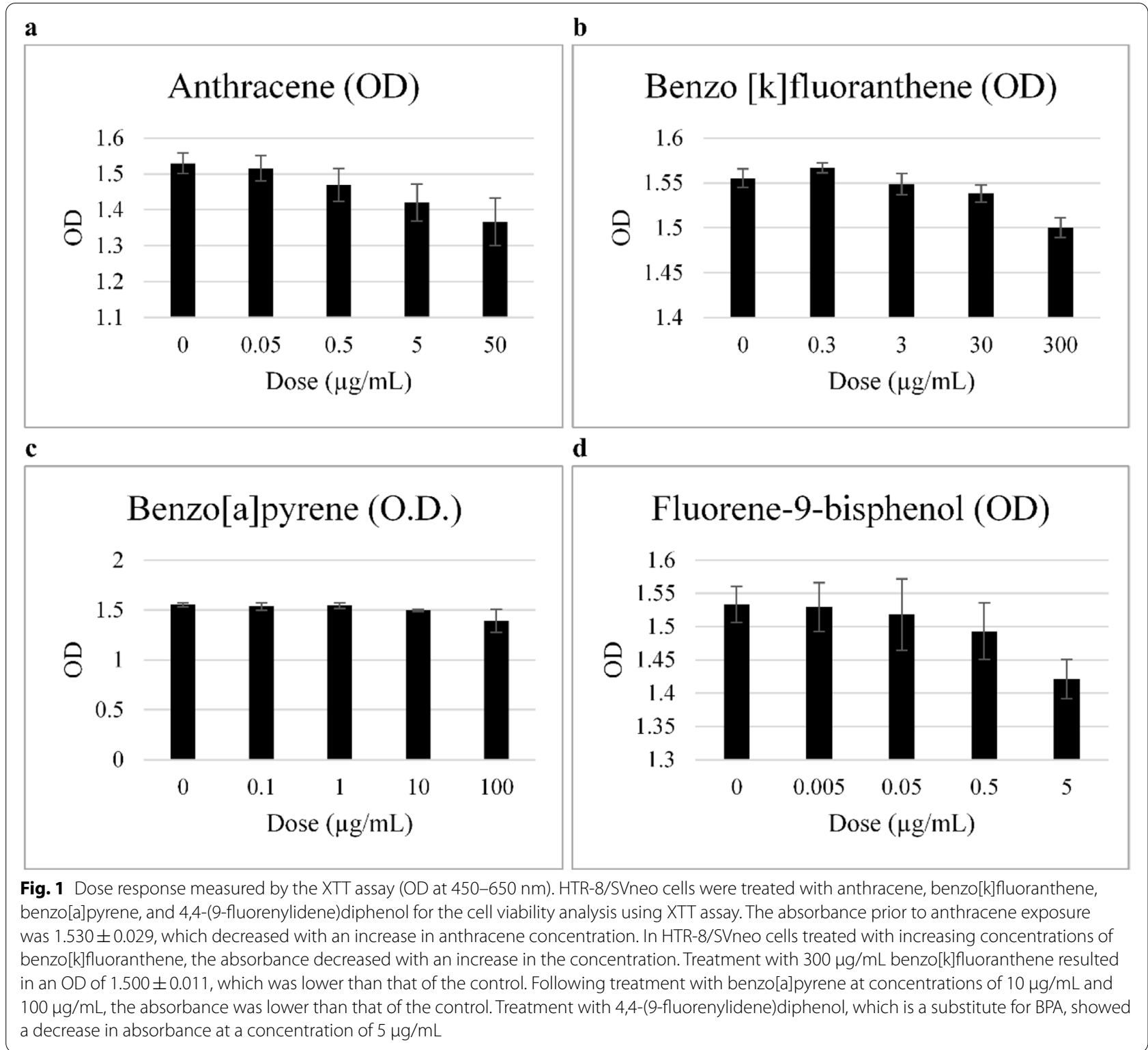

cell line of trophoblast and stromal cells. The HTR-8/SV neo cell line has been known as the primary extravillous trophoblast in previous studies. Although recently considered and tested as a placenta cell line, there are still many studies that consider it as a trophoblast cell and lead to results. Therefore, we applied it to our study as it is. Nevertheless, additional experiments are needed to determine which cells are actually affected.

Despite such limitation, our study has strengths. PAHs are stabilizers and plasticizers found in many consumer products, including toys and hygiene products. They are also used in blood bags, medical devices, adhesives, solvents, and pesticides [19, 20]. BPA and phthalate metabolites are detected in urinalysis in more than 90\% of pregnant women in the United States because of their high PAH exposure [21]. However, the effects of endocrine disruptors such as PAHs on the placenta have not been sufficiently studied despite pregnant women being exposed to them almost daily. In addition, most studies have focused only on BPA. Exposure to PAHs during pregnancy is an essential issue in teratogenicity and preterm birth, and adverse perinatal outcome continues to increase. Our study is meaningful in that it provides the basis for research on the correlation between PAHs and preterm birth by providing evidence that PAH exposure causes placental cell necrosis. Furthermore, our study 
Table 2 Absorbance of HTR8/SVneo according to time course

\begin{tabular}{|c|c|c|c|c|c|c|}
\hline \multirow{2}{*}{$\frac{\text { Materials }}{\text { Control (DMSO only) }}$} & \multirow{2}{*}{$\begin{array}{l}\text { Time course (h) } \\
0\end{array}$} & \multicolumn{4}{|c|}{ OD (Individuals) } & \multirow{2}{*}{$\frac{\text { OD (Total, } \boldsymbol{n}=\mathbf{4})}{1.558 \pm 0.035}$} \\
\hline & & 1.537 & 1.590 & 1.515 & 1.588 & \\
\hline & 24 & 1.72 & 1.784 & 1.707 & 1.812 & $1.756 \pm 0.046$ \\
\hline & 48 & 1.995 & 2.013 & 1.92 & 2.146 & $2.019 \pm 0.087$ \\
\hline & 72 & 2.008 & 2.104 & 1.971 & 2.231 & $2.079 \pm 0.107$ \\
\hline \multirow{4}{*}{$\begin{array}{l}\text { Anthracene } \\
(50 \mu \mathrm{g} / \mathrm{mL})\end{array}$} & 0 & 1.520 & 1.511 & 1.532 & 1.506 & $1.517 \pm 0.011$ \\
\hline & 24 & 1.373 & 1.451 & 1.470 & 1.312 & $1.402 \pm 0.068^{*}$ \\
\hline & 48 & 1.042 & 1.285 & 1.115 & 0.947 & $1.097 \pm 0.132^{* *}$ \\
\hline & 72 & 0.495 & 0.702 & 0.388 & 0.685 & $0.568 \pm 0.141^{* *}$ \\
\hline \multirow{4}{*}{$\begin{array}{l}\text { Benzo[k]fluoranthene (B[k]F) } \\
(300 \mu \mathrm{g} / \mathrm{mL})\end{array}$} & 0 & 1.562 & 1.519 & 1.563 & 1.524 & $1.545 \pm 0.025$ \\
\hline & 24 & 1.522 & 1.500 & 1.521 & 1.509 & $1.513 \pm 0.010^{*}$ \\
\hline & 48 & 1.509 & 1.471 & 1.510 & 1.490 & $1.495 \pm 0.017^{*}$ \\
\hline & 72 & 1.478 & 1.469 & 1.507 & 1.477 & $1.483 \pm 0.015^{* *}$ \\
\hline \multirow{4}{*}{$\begin{array}{l}\text { Benzo[a]pyrene (B[a]P) } \\
(100 \mu \mathrm{g} / \mathrm{mL})\end{array}$} & 0 & 1.582 & 1.560 & 1.549 & 1.522 & $1.553 \pm 0.023$ \\
\hline & 24 & 1.450 & 1.441 & 1.475 & 1.338 & $1.426 \pm 0.056^{* *}$ \\
\hline & 48 & 1.115 & 1.230 & 1.046 & 1.165 & $1.139 \pm 0.072^{* *}$ \\
\hline & 72 & 0.701 & 0.726 & 0.749 & 0.745 & $0.730 \pm 0.020^{* *}$ \\
\hline \multirow{4}{*}{$\begin{array}{l}\text { Fluorene-9-bisphenol (BHPF) } \\
(5 \mu \mathrm{g} / \mathrm{mL})\end{array}$} & 0 & 1.502 & 1.550 & 1.565 & 1.540 & $1.539 \pm 0.025$ \\
\hline & 24 & 1.411 & 1.453 & 1.400 & 1.410 & $1.419 \pm 0.022^{* *}$ \\
\hline & 48 & 1.380 & 1.414 & 1.317 & 1.392 & $1.376 \pm 0.039^{* *}$ \\
\hline & 72 & 1.225 & 1.375 & 1.186 & 1.159 & $1.236 \pm 0.089^{* *}$ \\
\hline
\end{tabular}

All values are mean \pm SEM. Significantly different from control; $p<0.05^{*}, p<0.005^{* *}$

\section{Viability (OD $450 \mathrm{~nm}$ and OD $650 \mathrm{~nm}$ )}

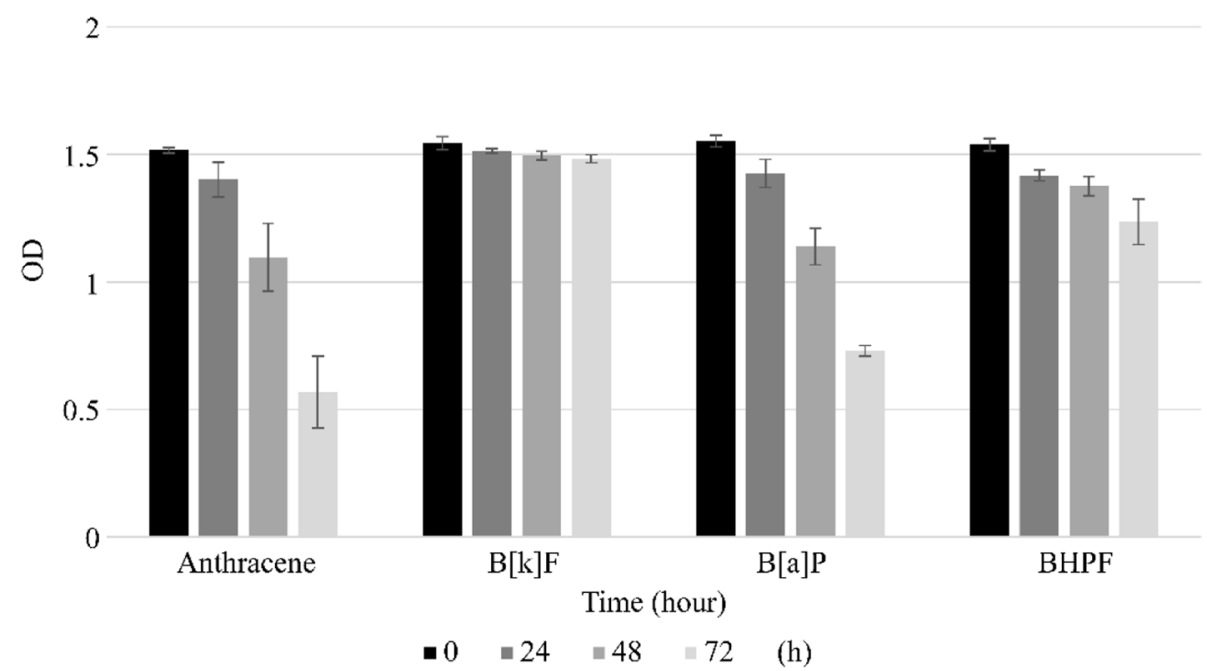

Fig. 2 Time course in the XTT assay (OD at 450-650 nm). HTR-8/SVneo cells were treated with anthracene, benzo[k]fluoranthene, benzo[a]pyrene, and 4,4-(9-fluorenylidene)diphenol at 24, 48, and $72 \mathrm{~h}$ for the time course analysis using XTT assay. Treatment of the cells with anthracene $(50 \mu \mathrm{g} /$ $\mathrm{mL}$ ) showed an initial absorbance of $1.517 \pm 0.011$, which showed a decreasing tendency with increasing time, decreasing to $1.402 \pm 0.068$ at $24 \mathrm{~h}, 1.097 \pm 0.132$ at $48 \mathrm{~h}$, and $0.568 \pm 0.141$ at $72 \mathrm{~h}$. The OD values obtained following $300 \mu \mathrm{g} / \mathrm{mL}$ benzo[k]fluoranthene treatment for 24,48 , and $72 \mathrm{~h}$ were also lower than the initial value. The absorbance following treatment with benzo [a]pyrene at a concentration of $100 \mu \mathrm{g} / \mathrm{mL} \mathrm{showed} \mathrm{a}$ decrease after $24 \mathrm{~h}$. Similar results were observed when the cells were treated with $5 \mu \mathrm{g} / \mathrm{mL}$ of 4,4-(9-fluorenylidene)diphenol. Compared with the initial OD value, the absorbance was lower than that of the control at $24 \mathrm{~h}, 48 \mathrm{~h}$, and $72 \mathrm{~h}$ 
showed an important finding that BPA substitutes are also unsafe PAHs.

\section{Conclusions}

Our study showed that anthracene, benzo[k]fluoranthene, benzo[a]pyrene, and 4,4'-(9-fluorenylidene)diphenol, a BPA substitute that has been insufficiently studied, affect cell proliferation and differentiation in a placental cell line. This means that these PAHs cause cell necrosis in the placenta, leading to adverse perinatal outcomes, such as preterm birth. These results can be used as basic data for future research related to preterm birth and PAHs.

\section{Abbreviations}

PAH: Polycyclic aromatic hydrocarbons; BPA: Bisphenol A; OD: Optical density.

\section{Acknowledgements}

Not applicable.

\section{Authors' contributions}

YSJ and HSK are the first authors participating in the study design and contributed equally to this work. AYK performed the experiments and analyzed the data. HGJ participated in the experiment. WJK participated in data interpretation. SKC is the corresponding author and participated in the design of the study, interpretation of the data, and drafting of the manuscript. All authors have read and approved the final manuscript.

\section{Funding}

The authors wish to acknowledge the financial support of the Catholic Medical Center Research Foundation in the program year of 2018.

\section{Availability of data and materials}

The datasets used and analyzed during the current study are available from the corresponding author on reasonable request.

\section{Declarations}

Ethics approval and consent to participate

Not applicable.

\section{Consent for publication}

Not applicable.

\section{Competing interests}

The authors declare that they have no competing interests.

Received: 28 October 2021 Accepted: 26 February 2022

Published online: 08 March 2022

\section{References}

1. Sanderson JT. The steroid hormone biosynthesis pathway as a target for endocrine-disrupting chemicals. Toxicol Sci. 2006;94:3-21.

2. Sweeney T. Is exposure to endocrine disrupting compounds during fetal/ post-natal development affecting the reproductive potential of farm animals? Domest Anim Endocrinol. 2002;23:203-9.

3. Patel S, Zhou C, Rattan S, Flaws JA. Effects of Endocrine-Disrupting Chemicals on the Ovary. Biol Reprod. 2015;93:20.

4. Woodruff TK, Walker CL. Fetal and early postnatal environmental exposures and reproductive health effects in the female. Fertil Steril. 2008;89:e47-51
5. Boström CE, Gerde P, Hanberg A, Jernström B, Johansson C, Kyrklund T, et al. Cancer risk assessment, indicators, and guidelines for polycyclic aromatic hydrocarbons in the ambient air. Environ Health Perspect. 2002;110(Suppl 3):451-88.

6. Miller KP, Borgeest C, Greenfeld C, Tomic D, Flaws JA. In utero effects of chemicals on reproductive tissues in females. Toxicol Appl Pharmacol. 2004;198:111-31.

7. Perera FP, Rauh V, Tsai WY, Kinney P, Camann D, Barr D, et al. Effects of transplacental exposure to environmental pollutants on birth outcomes in a multiethnic population. Environ Health Perspect. 2003;111:201-5.

8. Kim A, Park M, Yoon TK, Lee WS, Ko JJ, Lee K, et al. Maternal exposure to benzo[b]fluoranthene disturbs reproductive performance in male offspring mice. Toxicol Lett. 2011;203:54-61.

9. Le Vee M, Kolasa E, Jouan E, Collet N, Fardel O. Differentiation of human placental BeWo cells by the environmental contaminant benzo(a)pyrene. Chem Biol Interact. 2014;210:1-11.

10. Drwal E, Rak A, Grochowalski A, Milewicz T, Gregoraszczuk EL. Cell-specific and dose-dependent effects of PAHs on proliferation, cell cycle, and apoptosis protein expression and hormone secretion by placental cell lines. Toxicol Lett. 2017;280:10-9.

11. Rattan S, Zhou C, Chiang C, Mahalingam S, Brehm E, Flaws JA. Exposure to endocrine disruptors during adulthood: consequences for female fertility. J Endocrinol. 2017;233:R109-29.

12. Kaufmann P, Black S, Huppertz B. Endovascular trophoblast invasion: implications for the pathogenesis of intrauterine growth retardation and preeclampsia. Biol Reprod. 2003;69:1-7.

13. Woodruff TJ, Zota AR, Schwartz JM. Environmental chemicals in pregnant women in the United States: NHANES 2003-2004. Environ Health Perspect. 2011;119:878-85.

14. Veiga-Lopez A, Kannan K, Liao C, Ye W, Domino SE, Padmanabhan V. Gender-Specific Effects on Gestational Length and Birth Weight by Early Pregnancy BPA Exposure. J Clin Endocrinol Metab. 2015;100:E1394-403.

15. Adibi JJ, Hauser R, Williams PL, Whyatt RM, Calafat AM, Nelson H, et al. Maternal urinary metabolites of Di-(2-Ethylhexyl) phthalate in relation to the timing of labor in a US multicenter pregnancy cohort study. Am J Epidemiol. 2009;169:1015-24.

16. Ferguson KK, McElrath TF, Ko YA, Mukherjee B, Meeker JD. Variability in urinary phthalate metabolite levels across pregnancy and sensitive windows of exposure for the risk of preterm birth. Environ Int. 2014;70:118-24.

17. Felsenfeld G. A brief history of epigenetics. Cold Spring Harb Perspect Biol. 2014:6(1):p.a018200

18. Suter MA, Aagaard KM, Coarfa C, Robertson M, Zhou G, Jackson BP, et al. Association between elevated placental polycyclic aromatic hydrocarbons (PAHs) and PAH-DNA adducts from Superfund sites in Harris County, and increased risk of preterm birth (PTB). Biochem Biophys Res Commun. 2019:516:344-9.

19. Mervish N, MCGovern KJ, Teitelbaum SL, Pinney SM, Windham GC, Biro FM, et al. Dietary predictors of urinary environmental biomarkers in young girls, BCERP, 2004-7. Environ Res. 2014;133:12-9.

20. Newbern D, Freemark M. Placental hormones and the control of maternal metabolism and fetal growth. Curr Opin Endocrinol Diabetes Obes. 2011;18:409-16.

21. Heudorf U, Mersch-Sundermann V, Angerer J. Phthalates: toxicology and exposure. Int J Hyg Environ Health. 2007;210:623-34.

\section{Publisher's Note}

Springer Nature remains neutral with regard to jurisdictional claims in published maps and institutional affiliations. 